\author{
Professor Melike BÍLDİRİi, PhD \\ E-mail: melikebildirici@gmail.com \\ Yıldız Technical University, Department of Economics \\ Res. Ass. Fulya OZAKSOY SONUSTUN \\ E-mail: fulyaozaksoy @ gmail.com \\ Dogus University, Department of Economics
}

\title{
THE EFFECTS OF OIL AND GOLD PRICES ON G7 COUNTRIES
}

\begin{abstract}
The volatility of oil and gold prices has significant role on government's' economic policies and structures of business cycles. In this paper, it was aimed to analyze relation between gold and oil prices and their effects on the business cycle structures of the selected G7 countries. In this regard, MS-AR and MS-VAR models were selected to analyze gold and oil price volatilities, identify the business cycle structures and make effective economic policy inferences for each of the selected countries. Transition probabilities of this paper emphasize the asymmetric behavior of business cycles. More critically, economic policy results of this paper support that regime transition probabilities from modest growth to recession period is lower than transition probability from crisis regime to rapid growth stage. Besides, the findings reveal the importance of gold and oil prices on economic growth and welfare.
\end{abstract}

Keywords: Volatility of Oil and Gold Prices, MS-AR(X) analysis, MS$\operatorname{VAR}(X)$ analysis.

\section{JEL Classification: O40, Q41, Q43}

\section{Introduction}

Ever since industrialization and especially after World War II, many of the devices from simple devices to industrial machines, transportation, complex mechanical systems such as power generators and cars need to oil and oil products. Demand for petroleum increased by years because of rapid urbanization, modernization, changes in consumption habits of society, higher living standards. These important factors enhanced energy usage, frequently oil preference [1] particularly in emerging and developed countries such as China, Germany, India, the Republic of Korea, Russia, the USA, Thus, it is not amazing that crude oil has the highest share in the commodity market of the world and it is accepted as a leading economic indicator of the world economy.

Policy makers and economy authorities generally assume that fluctuations in crude oil prices figure as a significant determinant of the world economy and primary reason of business cycle fluctuations. This uncertainty causes to capital 
Melike Bildirici, Fulya Özaksoy Sonustun

and labor reallocations across sectors, postpone of investments and changes in future plannings of economies. This can be the main development problem of countries who forced to face with budget constraint by allocating oil with the other energy sources [2].

The volatility in prices of crude oil is defined as the tendency of crude oil prices to increase or decrease within a period of time. OPEC (Organization of the Petroleum Exporting Countries) takes active role in determining supply-demand equilibrium of petroleum which influence the volatility of international oil market. To evaluate oil price volatility, it is crucial to pay attention to after the period of 1945 because before this time, oil industry is in its infancy because there is insufficient technological progress and mining capacity.

Energy was directed by a number of the Western international oil companies before the Second World War. However, after Second World War, oil demand exhibited uptrend because of technological advancements and improvement in mining capacity of oil industry and rising oil necessities in most of the major oil importing countries [3].

On the other side, gold plays value storage role and does not effective in monetary system since the collapse of Bretton Wood system. Rather, it is opted for risk diversification, financial arbitrage, confidence in investment, insurance against market crises, economic security [4], 'safe heaven' against high volatility in commodity markets by investors, economists especially in economic crisis periods [5]. Because of its low volatility and its role of hedging against uncertainty leads to be evaluated as a wealth preserver during the inflationary times.

The volatility of oil and gold prices has prominent role in stage of business cycles because system dynamics of the economy and the volatility of other precious metals have relationship with the volatilities of oil and gold prices. The crude oil price increases are perceived as a tax revenue transferred from oil importer countries to oil exporter countries [6]. So, oil and gold price movements attracted great attention among economists because of their profound impact on economic policies.

Gold and oil are among the most substantial indicators of economies and their price movements sign to crucial implications for financial markets. Oil and gold prices are explained by inflation channel. Accordingly, high oil prices give rise to increase in transportation and production costs that give cause for rising in general price level. So, gold prices, using as a hedge against inflation, increase. This mechanism negatively impresses oil importing countries because of negative relationship between oil and inflation [7]. As a second mechanism, high oil prices have adverse impact on economic growth and diminish asset prices so, gold is retained as a store of value. The another mechanism considers oil-exporting countries, suggested by Melvin and Sultan [8]. Accordingly, if oil prices and revenues get high, these countries enhance their gold investments in their portfolios. This causes to increase in gold demand and following in its prices which affects oil prices [9]. 
The Effects of Oil and Gold Prices on G7 Countries

The above mentioned points lead to oil price volatility and besides, increases in other energy prices, rising costs in production input. This induces to fall in productivity and output. The Real Business Cycle Theory is gained to literature by Kydland and Prescott [10], indicates to oil price volatility which generates fluctuations in production levels of economies and so, in investment and employment opportunities.

Although, in the related literature, the studies mostly examine the oil and gold price volatility, the papers analyze their effects on economic growth are so scarce. The early paper investigated the inversed relation between oil price volatility and economic growth [11], and some papers [12] examined the relationship between oil price volatility and economic growth in the USA and the other selected countries.

Hamilton [11] made a significant contribution to the literature in which he drew attention to the relation between oil price increases and the macroeconomic variables such as unemployment, GNP in the United States. Adversely to Hamilton, Hooker [11] specified that oil prices have no correlations with the macroeconomic variables so, oil price increases are not Granger cause of GNP or unemployment rate. Following, asymmetric relationship between macroeconomic variables and oil prices was remarked by some papers [13]. On the other hand, some papers [14] analyzed the impact of oil shocks by Markov-Switching method for on the United Kingdom's and the United States' economies. Guo and Kliesen [15] found a significant and negative relationship between crude economic growth and oil prices for the time of 1984-2004 which confirms Hamilton's [16] findings. Cologni and Manera [17] tested the impacts of oil price on G7 economies by using MS-AR and MS-VAR model.

In this regard, this paper aims to examine the impacts of gold and oil price volatility on the business cycle structures of G7 countries (except Japan) which refers to dynamic relationship among oil price, gold price and economic growth. By examining the different business cycle asymmetries, it is purposed to specify the impacts of changes in gold and oil prices on the selected countries' economic growth in the different stages of the economies by using Markov Switching Auto Regressive (MS-AR) and Markov Switching Vector Auto Regressive (MS-VAR) methods.

The data and econometric methodology is shown in the second section. In the third section, the econometric results were identified. Finally, the last section includes the conclusion and policy implications.

\section{Data and Econometric Methodology}

\subsection{Data}

In this paper, the dataset was get from the Organization for Economic Cooperation and Development and International Monetary Fund (IMF), individual country statistic, and the Internationally Energy Agency (IEA) statistics for the 
period from 1968:1through 2015:12 for oil and gold prices; for the period from 1968:1 through 2014:4 for GDP of the countries. However, because of oil price stability, the data covers the period 1973:1-2015:12 and 1972:4-2015:4 was used. The oil price is measured as $\mathrm{LOP}=\log \left(\mathrm{OP}_{\mathrm{t}} / \mathrm{OP}_{\mathrm{t}-1}\right)$ and the other variables were obtained as $\mathrm{X}=\log \left(\mathrm{X}_{t} / \mathrm{X}_{\mathrm{t}-1}\right)$ for the MS-ARX and MS-VARX models.

\subsection{Econometric Methodology}

In the first part, MS-AR model is get to investigate the linkage between crude oil and gold prices. In the second part, the results of macroeconomic policy are discussed. While it was utilized from the MS-ARX models for business cycle analysis, in last stage, MS-VARX analysis for other macroeconomic policy result will be discussed.

\subsubsection{Markov Switching-AR Model}

In his pioneering study, as a choice of stationary linear autoregressive model, Hamilton [16] used a nonlinear simple model of econometric time series with a cyclical and permanent component. Following, Krolzig [18] developed MSVAR model which enable to analyze nonlinear dynamics and asymmetric structure of business cycles in macroeconomic models, extensively used in applied econometrics. Hamilton [22] modeled Markov Switching chain which allows positive and negative shocks asymmetrically, mostly used for analyzing business cycle fluctuations:

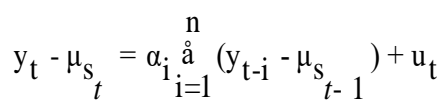

Where $m_{s t}$ is $m_{1} £ 0$ when $s_{t}=2$ and it is $m_{2} \mathrm{f} 0$ when $s_{t}=2$, and where $u_{t}: \operatorname{iidN}\left(0, s^{2}\right)$ when $|f| \mathrm{p} 1 . s_{t}$ is a discrete variable which gets values of 1 or 2. The probability of a two-rejime business cycle model consists in value $\mathrm{j}$ recent estimation of

$$
P\left\{s_{t}=j \mid s_{t-1}=1, s_{t-2}=k, \ldots \ldots . .\right\}=P\left\{s_{t}=j \mid s_{t-1}=i\right\}=p_{i j}
$$

The Markov chain is irreducible, ergodic. It is presumed that, by using the transition probabilities matrix, $\mathrm{s}_{\mathrm{t}}$ follows an irreducible ergodic state of Markov process:

For the theoretical properties, ergodicity and irreducibility assumptions are essential. With transition probabilities $p_{i j}$, a two-state Markov chain has unconditional distribution given by:

$$
\operatorname{Pr}\left(s_{t}=1\right)=\frac{1-p_{22}}{2-p_{11}-p_{22}}, \operatorname{Pr}\left(s_{t}=2\right)=\frac{1-p_{11}}{2-p_{11}-p_{22}}
$$


The Effects of Oil and Gold Prices on G7 Countries

\subsubsection{Specification of the Model}

The dynamic linkages among real GDP of countries, oil price and gold price are tested by adding lagged coefficients and volatility of gold and oil prices. Model specifications are written only for the first model [17].

Firstly, it is estimated using MSI intercept (MSI) model is

$$
\begin{gathered}
\mathrm{D} g d p_{t}=c\left(s_{t}\right)+\underset{i=1}{\stackrel{p}{a}} a_{i} \mathrm{D} g d p_{t-i}+\underset{j=1}{\stackrel{q}{a}} g_{j} O P_{t-j}+\underset{k=1}{\stackrel{a}{n}} q_{k} A P_{t-k}+e_{t} \\
e_{t}: \operatorname{iid}\left(0, s^{2}\right)
\end{gathered}
$$

where $\mathrm{OP}_{t}$ represents the oil price volatility, $\mathrm{AP}_{t}$ shows the gold price volatility. Especially in recession periods, the output volatility is varies from the volatility that determines economic conditions by disturbance term variances.

$$
e_{t}: \operatorname{iid}\left(0, s^{2}\left(s_{t}\right)\right)
$$

The MSI-heteroskedastic model (MSIH) is the combination of equations (5) and (6).

\subsubsection{MarkovSwitching - VAR}

MSI(.)-VAR(.) model is

$$
y_{t}=c\left(s_{t}\right)+\underset{k=1}{p} A_{k}\left(s_{t}\right) y_{t-k}+u_{t}
$$

where $y_{o}, \ldots \ldots ., y_{1-k}$ are fixed, all parameters are regime $\left(s_{t}\right)$ dependent, $v\left(s_{t}\right)$ represents shift functions (mean or intercept), $A_{1}\left(s_{t}\right) y_{t-1}+\ldots \ldots .+A_{k}\left(s_{t}\right) y_{t-k}$ represents the lagged value coefficients of the variables, a $\left(s_{t}\right)$ shows variance of the residuals.

\section{Econometric Results}

The procedure of model selection in this paper follows AIC, LL and LR tests.

\subsection{Univariate MS models}

There are two econometric results; the results for volatility of oil and gold prices and the result for countries.

\subsubsection{The results for Oil Volatility and Gold Price}

In this study, the impact of oil price on the gold price and the impact of gold price on the oil price were analyzed by MSIH(2)-ARX(4) models over 1972(2)-2015(12) period. Firstly, AP was taken as dependent variable. The regime 
Melike Bildirici, Fulya Özaksoy Sonustun

2 is a signal to the persistent phases. This situation describes the presence of important asymmetries. Secondly, oil price is considered as dependent variable. Oil and gold prices have significant effect on each other's. Besides, their standard errors are so high in their first regimes. In regime 1, standard error is larger; this situation suggests higher volatility. The recessionary states show a sharp increase in the standard error variabilities which signify that recession terms are less stable than expansion periods.

Table 1. The Results of AP and OP Model

\begin{tabular}{|l|l|l|l|}
\hline \multicolumn{2}{|l|}{ Dependent variable: AP } & \multicolumn{2}{|c|}{ Dependent variable: OP } \\
\hline \multicolumn{2}{|c|}{ MSIH(2)-ARX(4) } & \multicolumn{2}{|c|}{ MSIH(2)-ARX(4) } \\
\hline Reg. -specific Intercept & Regime-specific Intercept \\
\hline c(Reg.1) & $-0,04(-4,17)$ & c(Reg.1) & $0,023(0.52)$ \\
\hline c(Reg.2) & $0,01(2.49)$ & c(Reg.2) & $0,011(1.22)$ \\
\hline Regime-specific autoregressive coefficients \\
\hline LAP & LAP & $-0,04(2.09)$ \\
\hline LAP-1 & $0,20(2.88)$ & LAP-1 & $0,19(3.5)$ \\
\hline LAP-2 & $-0,15(2.89)$ & LAP-2 & $-0,15(2.91)$ \\
\hline LAP-3 & $0,13(2.48)$ & LAP-3 & $0,061(2.6)$ \\
\hline LAP-4 & $0,05(2.11)$ & LAP-4 & $0,019(2.98)$ \\
\hline LOP & $-0,11(0.12)$ & LOP & - \\
\hline LOP1-1 & $0,07(2.31)$ & LOP1-1 & $0,31(2.1)$ \\
\hline LOP1-2 & $0,09(2.13)$ & LOP1-2 & $0,14(2.09)$ \\
\hline LOP1-3 & $0,71(2.11)$ & LOP1-3 & $-0,01(3.01)$ \\
\hline LOP1-4 & $-0,11(1.56)$ & LOP1-4 & $0,03(1.5)$ \\
\hline \multicolumn{5}{|c|}{ Regime-specific standard error } \\
\hline SE(R1) & 0,92 & SE(R1) & 0.991 \\
\hline SE(R2) & 0,0201 & SE(R2) & 0.0432 \\
\hline \multicolumn{5}{|c|}{ Transition probabilities } \\
\hline P11 & 0.9117 & P 11 & 0.9181 \\
\hline P 22 & 0.9642 & P 22 & 0.96 \\
\hline LL & 895.8384 & LL & 678.8990 \\
\hline AIC & 3.845 & AIC & -4.12436 \\
\hline \multicolumn{5}{|l|}{162.2541} & 129.3938 \\
LR & $\begin{array}{l}\text { Chi(2)=[0.00] } \\
\text { DAVIES=[0.00] }\end{array}$ & LR & Chi(2)=[0.000] \\
DAVIES=[0.00] \\
\hline
\end{tabular}

\subsubsection{The Results for Countries}

In this paper, MS-ARX models were selected for capturing the 2 or 3 regimes for Canada, Germany, Italy, United Kingdom, France and the USA. Table 2 show crisis dating determined by selected models and ECRI crisis dating. 
The Effects of Oil and Gold Prices on G7 Countries

Table 2. Crisis Dating

\begin{tabular}{|l|l|l|l|l|l|}
\hline ECRI & Canada & ECRI & Germany & ECRI & UK \\
\hline & & $73: 3-75: 3$ & $73: 3-75: 3$ & $74: 3-75: 2$ & $74: 3-75: 4$ \\
\hline & & & & $79: 3-81: 2$ & $79: 4-81: 2$ \\
\hline $81: 2-82: 4$ & $81: 3-82: 3$ & $80: 1-82: 4$ & $80: 2-83: 3$ & & \\
\hline $90: 1-92: 1$ & $90: 2-92: 4$ & $91: 1-94: 2$ & $91: 2-92: 2$ & $90: 2-92: 1$ & $91: 3-93: 2$ \\
\hline & & $01: 1-03: 3$ & $01: 2-04: 2$ & & $02: 3-03: 3$ \\
\hline $08: 01-09: 3$ & $07: 4-09: 4$ & $08: 04-09: 1$ & $08: 2-09: 4$ & $08: 5-10: 1$ & $07: 4-10: 2$ \\
\hline ECRI & USA & ECRI & Italy & ECRI & France \\
\hline & & $70: 4-71: 3$ & & & \\
\hline $73: 4-75: 1$ & $74: 1-75: 2$ & $74: 2-75: 2$ & $74: 2-75: 2$ & $74: 2-75: 1$ & $74: 3-75: 1$ \\
\hline & & & $79: 3-79: 4$ & & \\
\hline $\begin{array}{l}80: 1-80: 3 \\
81: 3-82: 4\end{array}$ & $80: 2-82: 4$ & $80: 2-83: 2$ & $81: 3-83: 3$ & $82: 2-83: 2$ & $81: 4-83: 2$ \\
\hline $90: 3-91: 1$ & $90: 3-91: 3$ & $92: 1-93: 4$ & $92: 2-93: 2$ & $90: 2-91: 4$ & $90: 4-91: 4$ \\
\hline $01: 1-01: 4$ & $02: 2-03: 1$ & & & & \\
\hline $07: 4-09: 3$ & $07: 4-09: 2$ & $07: 3-10: 1$ & $08: 2-09: 4$ & & $09: 2-10: 1$ \\
\hline
\end{tabular}

In this analysis, $\mathrm{OP}$ and $\mathrm{AP}$ variables were taken as exogenous for univariate MS(.)-ARX(.) models (Table 2). Oil prices are determined by oil producer countries' decision and the other factors. Although US and Canada are remarkable oil producer countries, they do not specify oil market price by themselves. The other countries are not sufficient in oil price determination process. Gold prices are settled by the other determinants. For these reasons, oil and gold prices were accepted as exogenous in this study. For Canada it is determined that $\operatorname{MSIH}(2)$ ARX(4) specification presents the best empirical results with statistically significant coefficients. Canadian business cycle reported in Table 2 coincides with ECRI if compared with ECRI business cycle dating. In MSIH(2)-ARX(4) model for Canada, the first regime detects the periods of recessions: 1981:3-1982:3, 1990:2-1992:4 and 2007:4-2009:4. Altuğ and Bildirici [19] consider 3-regimes model for the Canadian business cycle. For Canada, the distributed-lag component coefficients of oil-price are statistically significant and negative and the first coefficient of distributed-lag component of AP variable is statistically significant and negative but $\mathrm{AP}(-2)$ and $\mathrm{AP}(-3)$ are statistically insignificant. The regime 2 is the more persistent than regime 1 with a persistence probability of 0.96 . The average duration of each regime, being consistent with this result is varied. Parameter estimations of OP and AP variables accept that price volatilities of oil and gold have small effects on GDP. 
Melike Bildirici, Fulya Özaksoy Sonustun

Table 3. The results of Canada, Germany, UK

\begin{tabular}{|c|c|c|c|c|c|c|c|}
\hline \multicolumn{2}{|c|}{$\begin{array}{l}\text { MSIH(2)-ARX(4) for } \\
\text { Canada }\end{array}$} & \multicolumn{4}{|c|}{ MSIA(3)-ARX(4) for Germany } & \multicolumn{2}{|c|}{ MSIH(3)-ARX(4) for UK } \\
\hline \multicolumn{8}{|c|}{ Regime-specific Intercept } \\
\hline $\mathrm{c}($ Reg.1) & $\begin{array}{l}-0.18 \\
(-2.4)\end{array}$ & \multicolumn{2}{|l|}{ c(Reg.1) } & \multicolumn{2}{|c|}{$\begin{array}{r}0.28 \\
(1.9)\end{array}$} & $\mathrm{c}($ Reg. 1$)$ & $\begin{array}{c}0.18 \\
(0.43)\end{array}$ \\
\hline $\mathrm{c}($ Reg.2) & $\begin{array}{c}1.22 \\
(1.87)\end{array}$ & \multicolumn{2}{|l|}{$\mathrm{c}($ Reg.2) } & \multicolumn{2}{|c|}{$\begin{array}{l}0.71 \\
(2.7)\end{array}$} & $\mathrm{c}($ Reg.2) & $\begin{array}{l}0.74 \\
(3.5)\end{array}$ \\
\hline & & \multicolumn{2}{|l|}{$c(\operatorname{Reg} 3)$} & \multicolumn{2}{|c|}{$\begin{array}{l}0.699 \\
(2.2)\end{array}$} & c(Reg3) & $\begin{array}{c}0.63 \\
(3.66) \\
\end{array}$ \\
\hline \multicolumn{8}{|c|}{ Regime-specific autoregressive coefficient } \\
\hline CY(-1) & $\begin{array}{l}0.96 \\
(3.4)\end{array}$ & $\mathrm{GY}(-1)$ & $\begin{array}{l}11.56 \\
(9.6)\end{array}$ & $\begin{array}{c}0.6 \\
(73.3)\end{array}$ & $\begin{array}{c}0.5 \\
(65.6)\end{array}$ & UKY $(-1)$ & $\begin{array}{c}0.64 \\
(2.25)\end{array}$ \\
\hline CY $(-2)$ & $\begin{array}{l}-0.33 \\
(-3.0)\end{array}$ & GY(-2) & $\begin{array}{l}-0.99 \\
(-4.3)\end{array}$ & $\begin{array}{c}0.04 \\
(0.56)\end{array}$ & $\begin{array}{c}0.2 \\
(23.56)\end{array}$ & UKY $(-2)$ & $\begin{array}{c}-0.16 \\
(-2.18)\end{array}$ \\
\hline CY(-3) & $\begin{array}{l}0.24 \\
(2.3)\end{array}$ & GY(-3) & $\begin{array}{c}-0.4 \\
(-26.6)\end{array}$ & $\begin{array}{c}0.19 \\
(23.37)\end{array}$ & $\begin{array}{c}0.34 \\
(31.1)\end{array}$ & UKY $(-3)$ & $\begin{array}{l}0.155 \\
(2.22)\end{array}$ \\
\hline CY $(-4)$ & $\begin{array}{l}-0.26 \\
(-3.9) \\
\end{array}$ & GY(-4) & $\begin{array}{c}0.29 \\
(21.7) \\
\end{array}$ & $\begin{array}{c}-0.29 \\
(-50.1) \\
\end{array}$ & $\begin{array}{c}-0.3 \\
(-42.5)\end{array}$ & UKY(-4) & $\begin{array}{c}-0.11 \\
(-3.11) \\
\end{array}$ \\
\hline LOP & $\begin{array}{l}0.013 \\
(1.91)\end{array}$ & LOP & $\begin{array}{l}-0.01 \\
(-0.9)\end{array}$ & $\begin{array}{c}0.04 \\
(12.42)\end{array}$ & $\begin{array}{l}-0.05 \\
(-12.5)\end{array}$ & LOP & $\begin{array}{l}0.21 \\
(0.1)\end{array}$ \\
\hline $\mathrm{LOP}(-1)$ & $\begin{array}{c}-0.11 \\
(-3.06)\end{array}$ & LOP(-1) & $\begin{array}{c}-0.6 \\
(-36.7)\end{array}$ & $\begin{array}{l}-0.03 \\
(-0.94)\end{array}$ & $\begin{array}{l}0.01 \\
(0.3)\end{array}$ & $\mathrm{LOP}(-1)$ & $\begin{array}{l}-1.2 \\
(-0.8)\end{array}$ \\
\hline $\mathrm{LOP}(-2)$ & $\begin{array}{l}-0.11 \\
(-2.24)\end{array}$ & $\mathrm{LOP}(-2)$ & $\begin{array}{c}-0.3 \\
(-27.8)\end{array}$ & $\begin{array}{c}0.05 \\
(17.36)\end{array}$ & $\begin{array}{c}-0.02(- \\
0.8)\end{array}$ & $\mathrm{LOP}(-2)$ & $\begin{array}{l}-0.41 \\
(-0.2)\end{array}$ \\
\hline $\mathrm{LOP}(-3)$ & $\begin{array}{c}-0.11 \\
(-2.16) \\
\end{array}$ & $\mathrm{LOP}(-3)$ & $\begin{array}{c}-0.2 \\
(-21.3) \\
\end{array}$ & $\begin{array}{c}-0.06 \\
(-28.8) \\
\end{array}$ & $\begin{array}{c}-0.03 \\
(-12.7)\end{array}$ & $\operatorname{LOP}(-3)$ & $\begin{array}{c}-0.11 \\
(-3.12) \\
\end{array}$ \\
\hline $\mathrm{LOP}(-4)$ & $\begin{array}{l}-0.02 \\
(-16.2)\end{array}$ & $\mathrm{LOP}(-4)$ & $\begin{array}{l}-0.02 \\
(-0.7)\end{array}$ & $\begin{array}{l}0.029 \\
(15.9)\end{array}$ & $\begin{array}{c}0.01 \\
(0.48)\end{array}$ & $\mathrm{LOP}(-4)$ & $\begin{array}{c}-0.21 \\
(-2.16) \\
\end{array}$ \\
\hline AP & $\begin{array}{c}-0.003 \\
(-0.1)\end{array}$ & AP & $\begin{array}{c}0.01 \\
(0.28)\end{array}$ & $\begin{array}{l}0.005 \\
(15.5)\end{array}$ & $\begin{array}{c}0.01 \\
(0.79)\end{array}$ & AP & $\begin{array}{l}-0.01 \\
(-0.22)\end{array}$ \\
\hline $\mathrm{AP}(-1)$ & $\begin{array}{l}-0.004 \\
(-14.5)\end{array}$ & $\mathrm{AP}(-1)$ & $\begin{array}{c}0.02 \\
(0.06)\end{array}$ & $\begin{array}{l}0.005 \\
(12.9)\end{array}$ & $\begin{array}{l}0.005 \\
(0.09)\end{array}$ & $\mathrm{AP}(-1)$ & $\begin{array}{c}-0.0004 \\
(-0.1)\end{array}$ \\
\hline $\mathrm{AP}(-2)$ & $\begin{array}{l}0.001 \\
(0.6)\end{array}$ & $\mathrm{AP}(-2)$ & $\begin{array}{c}0.002 \\
(0.7)\end{array}$ & $\begin{array}{c}-0.01 \\
(-37.4)\end{array}$ & $\begin{array}{c}0.01 \\
(-3.42)\end{array}$ & $\mathrm{AP}(-2)$ & $\begin{array}{c}-0.0001 \\
(-0.1)\end{array}$ \\
\hline $\mathrm{AP}(-3)$ & $\begin{array}{c}0.08 \\
(0.27)\end{array}$ & $\mathrm{AP}(-3)$ & $\begin{array}{c}-0.003 \\
(-.97)\end{array}$ & $\begin{array}{l}0.005 \\
(14.7)\end{array}$ & $\begin{array}{c}-0.2 \\
(0.55)\end{array}$ & $\mathrm{AP}(-3)$ & $\begin{array}{c}-0.0001 \\
(-0.11)\end{array}$ \\
\hline $\mathrm{AP}(-4)$ & $\begin{array}{c}0.029 \\
(10.31)\end{array}$ & $\mathrm{AP}(-4)$ & $\begin{array}{l}0.004 \\
16.1)\end{array}$ & $\begin{array}{c}-0.007 \\
(-2.8)\end{array}$ & $\begin{array}{l}0.004 \\
(-3.0)\end{array}$ & $\mathrm{AP}(-4)$ & $\begin{array}{c}0.004 \\
(3.11)\end{array}$ \\
\hline \multicolumn{8}{|c|}{ Regime-Specific Standart Error } \\
\hline SE(R1) & 0,8001 & $\mathrm{SE}(\mathrm{R} 1)$ & 0,5288 & 0.528 & 0.52882 & $\mathrm{SE}(\mathrm{R} 1)$ & 0.995 \\
\hline \multirow[t]{2}{*}{$\mathrm{SE}(\mathrm{R} 2)$} & 0.6235 & & & & & $\mathrm{SE}(\mathrm{R} 2)$ & 0.35 \\
\hline & & & & & & SE(R3) & 0.80 \\
\hline & & & ansition 1 & babilities & & & \\
\hline $\mathrm{P}_{11}$ & 0.8174 & $\mathrm{P}_{11}$ & 0.8147 & & & $P_{11}$ & 0.94 \\
\hline $\mathrm{P}_{22}$ & 0.958 & $\mathrm{P}_{22}$ & 0.8002 & & & $P_{22}$ & 0.954 \\
\hline & & $\mathrm{P}_{33}$ & 0.6101 & & & $P_{33}$ & 0.919 \\
\hline
\end{tabular}


The Effects of Oil and Gold Prices on G7 Countries

The roles of oil and gold prices on GDP of Germany are assessed with the MSIA(3)-ARX(4) model in Table 3. The different stages of economies is associated with three regimes which are high, moderate and null economic growth. In regime 1 , the coefficients of $\mathrm{OP}(-1), \mathrm{OP}(-2)$ and $\mathrm{OP}(-3)$ are statistically significant. The parameter estimate of $\mathrm{OP}(-1)$ is important with -0.5778 . In Regime 1, the effects on GDP of OP are negative and statistically significant. The coefficients of AP except AP(-4) are statistically insignificant but in Regime 2, all coefficients of AP are statistically significant. The coefficients of AP(-2) and AP(4) are positive and statistically significant in Regime 3, but all parameter estimations are low. In all regimes, the parameter estimations of OP is statistically significant and the parameter estimations of $\mathrm{OP}(-1)$ and $\mathrm{OP}(-2)$ in regime 1 are high. Regime 2 is moderate growth which is found as the most persistent and it is also verified by the average duration of each regimes. On the other side, the computed probability (i.e. $\operatorname{Prob}(\mathrm{st}=3 \mid \mathrm{st}-1=1)=0.1408$ ) points the low chance of a recession period is succeeded by a high growth period. Also, the computed probability (i.e. Prob(st $=2 \mid s t-1=1)=0.0305$ ) reflects the lower chance that recession is followed by a period of high growth. The probability of shifting from high regime of economy to the crisis regime is higher than the probability of shifting to the crisis regime of growth phase. The results of Prob(st $=1 \mid \mathrm{st}-1=$ 1) $=0.8147, \operatorname{Prob}(\mathrm{st}=2 \mid \mathrm{st}-1=2)=0.8002$ and $\operatorname{Prob}(\mathrm{st}=3 \mid \mathrm{st}-1=3)=0.6101$ indicate the persistence of regimes. Ergodic probabilities reveal that dominant regime is the second regime and transition probabilities, p11 $=0.24, \mathrm{p} 22=0.52$ and p33 $=0.23$ report the important asymmetries.

For UK, in MSIH(3)-ARX(4) model, as the first regime characterizing the periods, nearly best approximates recession dates reported by ECRI. Regime 2 that is moderate growth phase of economy is found as the most persistent that is affirmed by the average duration of each regime. On the other hand, the estimated probability (i.e. Prob(st $=3 \mid \mathrm{st}-1=1)=0.03904)$ refers to the low chance of a recession term is succeeded by a higher growth period. The results of Prob(st $=1 \mid \mathrm{st}-1=1)=0.911, \operatorname{Prob}(\mathrm{st}=2 \mid \mathrm{st}-1=2)=0.954$ and $\operatorname{Prob}(\mathrm{st}=3 \mid \mathrm{st}-1=3)=0.919$ have shown the persistence of regimes. In regime 1, standard error is larger; this situation suggests higher volatility. The recessionary states show a sharp increase in the standard error variabilities which signify that recession terms are less stable than expansion periods. In other respects, moderate growth rate circles are simplified by relatively smaller residual standard errors (Cologni and Manera [17]).

In Table 4, MSIH(2)-ARX(4) model was determined for the United States. Altuğ and Bildirici [19], and Cologni and Manera [17] consider 3-regimes model for the United State's business cycle. The transition probabilities of each of the two regimes refer that the second regime is high in line with $\operatorname{Prob}(\mathrm{st}=2 \mid \mathrm{st}-1=2)=$ 0.9402 . The recessionary state signs to a probability succeeded by a higher growth 
Melike Bildirici, Fulya Özaksoy Sonustun

term $(\operatorname{Prob}(\mathrm{st}=2 \mid \mathrm{st}-1=1)=0.049)$. AP variables except of $\mathrm{AP}$ and $\mathrm{AP}(-4)$ are statistically insignificant.

For France, in Table 4, the MSIH(3)-ARX(1) model was chosen to describe the important changes in gold and oil prices. The first regime characterizes the periods which approximate the recession dates of ECRI (Table 2). The estimated probability (i.e. Prob(st $=2 \mid \mathrm{st}-1=1)=0.15$ ) signs to low chance of a recession is succeeded by a moderate growth period. On the other hand, the computed probability (i.e. $\operatorname{Prob}(\mathrm{st}=3 \mid \mathrm{st}-1=1)=0.065)$ reflects the lowest chance that a recession is followed by a period of high growth. The results of $\operatorname{Prob}(\mathrm{st}=$ $1 \mid \mathrm{st}-1=1)=0.7801$, Prob(st $=2 \mid \mathrm{st}-1=2)=0.932$ and Prob $(\mathrm{st}=3 \mid \mathrm{st}-1=3)=$ 0.9533 sign to the persistence of regimes. Ergodic probabilities show that dominant regime is the second one. This situation indicates to important asymmetries in the business cycle. According to our results, in high growth periods, a sharp increase in standard error variabilities argues that high growth regimes are less stable than the other regimes. On the other side, moderate growth dates are associated to relatively smaller standard errors. The parameter estimation of $\mathrm{AP}(-1)$ is very important.

Table 4. The results of the USA, France and Italy

\begin{tabular}{|c|c|c|c|c|c|}
\hline \multicolumn{2}{|c|}{ MSIH(2)-ARX(4) for USA } & \multicolumn{2}{|c|}{ MSIH(3)-ARX(1) for France } & \multicolumn{2}{|c|}{ MSIH(3)-ARX(4) for Italy } \\
\hline \multicolumn{6}{|c|}{ Regime -specific Intercept } \\
\hline & Coefficient & & Coefficient & & Coefficient \\
\hline $\mathrm{c}($ Reg.1) & $0.080(0.27)$ & $\mathrm{c}($ Reg.1) & $2.37(15.373)$ & $\mathrm{c}($ Reg.1) & $0.6497(66.85)$ \\
\hline \multirow[t]{2}{*}{$\mathrm{c}$ (Reg.2) } & $1.49(4.67)$ & c(Reg.2) & $4.48(28.778)$ & $\mathrm{c}($ Reg.2) & $0.8213(1.09)$ \\
\hline & & $\mathrm{c}($ Reg.3) & $4.65(28.097)$ & $\mathrm{c}($ Reg.3) & $0.7427(5.27)$ \\
\hline \multicolumn{6}{|c|}{ Regime -Specific Autoregressive Coefficients } \\
\hline USY(-1) & $0.76(9.11)$ & $\mathrm{FY}(-1)$ & $0.603(10.19)$ & LY(-1) & $0.43(42.96)$ \\
\hline USY(-2) & $-0.01(-0.25)$ & LOP & $-0.28(-18.73)$ & $\mathrm{LY}(-2)$ & $-0.10(2.31)$ \\
\hline USY(-3) & $-0.119(-0.11)$ & LOP -1 & $-0.09(-6.206)$ & $\mathrm{LY}(-3)$ & $-0.01(2.14)$ \\
\hline USY(-4) & $-0.116(-1.99)$ & LAP & $0.054(4.25)$ & $\mathrm{LY}(-4)$ & $0.03(2.35)$ \\
\hline LOP & $0.022(0.41)$ & LAP -1 & $-2.88(-2.53)$ & LOP & $0.02(74.93)$ \\
\hline LOP1-1 & $-0.11(-2.88)$ & & & $\operatorname{LOP}(-1)$ & $-0.42(-3.48)$ \\
\hline LOP1-2 & $-0.11(-2.13)$ & & & LOP $(-2)$ & $-0196(-16.79)$ \\
\hline LOP1-3 & $-0.10(-1.97)$ & & & LOP $(-3)$ & $-0.0007(-1.40)$ \\
\hline LOP1-4 & $-0.031(-1.98)$ & & & $\operatorname{LOP}(-4)$ & $-0.006(-1.995)$ \\
\hline LAP & $-0.011(-2.35)$ & & & LAP & $-0,27(-3.23)$ \\
\hline LAP-1 & $-0.001(-0.21)$ & & & $\operatorname{LAP}(-1)$ & $-0,39(-4.94)$ \\
\hline LAP-2 & $-0.0008(-0.2)$ & & & LAP(-2) & $-0.019(-2.85)$ \\
\hline LAP-3 & $0.011(0.59)$ & & & $\operatorname{LAP}(-3)$ & $0.002(2.85)$ \\
\hline LAP-4 & $0.116(2.94)$ & & & $\operatorname{LAP}(-4)$ & $0.0016(2.32)$ \\
\hline \multicolumn{6}{|c|}{ Regime-Specific S.E. } \\
\hline SE(Reg.1) & 0,84 & SE(Reg.1) & 0.72203 & SE (Reg1) & 0.985 \\
\hline \multirow[t]{2}{*}{ SE(Reg.2) } & 0.55 & SE(Reg.2) & 0.78328 & SE (Reg2) & 0.3305 \\
\hline & & SE(Reg,3) & 18.986 & SE (Reg3) & 0.1102 \\
\hline \multicolumn{6}{|c|}{ Transition Probabilities } \\
\hline $\mathrm{P}_{11}$ & 0.850 & $\mathrm{P}_{11}$ & 0.7801 & $\mathrm{P}_{11}$ & 0.6835 \\
\hline \multirow[t]{2}{*}{$\mathrm{P}_{22}$} & 0.9402 & $\mathrm{P}_{22}$ & 0.932 & $\mathrm{P}_{22}$ & 0.9564 \\
\hline & & $\mathrm{P}_{33}$ & 0.9533 & $\mathrm{P}_{33}$ & 0.65 \\
\hline
\end{tabular}


The Effects of Oil and Gold Prices on G7 Countries

\begin{tabular}{|c|c|c|}
\hline $\begin{array}{l}\text { LL: } 225.71 \text { linear system : - } \\
\text { 228.3; AIC; } 3.110 ; \text { LR } \\
\text { 77.5268, Chi }(30)=[0.0000], \\
\text { Chi(36) }=[0.0001], \\
\text { DAVIES }=[0.0002]\end{array}$ & $\begin{array}{l}\text { LL: }-280.0597 \text { linear system: - } \\
\text { 305.4834; AIC: } 2,8711 ; \text { LR: } \\
\text { 50.8474,Chi(4) }=[0.0001], \\
\text { Chi(10) }=[0.0000], \\
\text { DAVIES }=[0.0000]\end{array}$ & $\begin{array}{l}\text { LL; 527.0005 linear system: } \\
\text { 546.688; AIC; }-4.01: \\
\text { LR; 160.6237 Chi }(32) \\
=[0.0000] \mathrm{Chi}(38)=[0.0000] \\
\text { DAVIES }=[0.0000]\end{array}$ \\
\hline
\end{tabular}

The roles of oil and gold prices in Italian GDP are assessed with the MSIH(3)-ARX(4) model (Table 4). According to parameter estimations, volatility of oil price has important effects. The first regime characterizes the approximately recession periods of ECRI. Italian economy reflects moderate growth phase that is found as the most persistent, which is also verified by the average duration of each regimes. The possibility of shifting from higher regime of economy to crisis regime is more than the possibility of shifting from rapid growth periods to the crisis regimes. The results of $\operatorname{Prob}(\mathrm{st}=1 \mid \mathrm{st}-1=1)=0.6835$, $\operatorname{Prob}(\mathrm{st}=2 \mid \mathrm{st}-1=2)=$ 0.9564 and $\operatorname{Prob}(\mathrm{st}=3 \mid \mathrm{st}-1=3)=0.6761$ have determined the persistence of regimes.

Transition probabilities report the important asymmetries in business cycle. In regime 1, standard error is larger; this situation suggests higher volatility. The recessionary state shows a sharp increase in the variability of the standard error which notes that recession periods are less stable than economic expansion periods. The regime 2 signals the most persistent phases. In regime 1, parameter estimations of $\mathrm{OP}(-1), \mathrm{OP}(-2), \mathrm{AP}$ and $\mathrm{AP}(-1)$ are negative and important but other parameter estimations of $\mathrm{OP}$ and $\mathrm{AP}$ variables are very low.

Parameter estimations and the regime specification of the model were significantly improved by asymmetric structures of oil and gold prices. In all models, since the LR test is significant, the oil and gold price variables are statistically significant at any significance levels. It seems that there are effects of oil shocks in crisis and growth phases. In MS-ARX models, the countries were gathered in two groups. The first of which is modelled with two regimes and the others with three regimes. MSIH(2)-ARX(4) model was accepted for Canada and the USA. The results of transition probabilities of regimes determined the persistence of the regimes and the transition probabilities of regimes are very persistent and close to another one. The durations of regime 1 is close to each other for both countries. In the other group, MSIH(3) model for UK and Italy, and $\operatorname{MSIA}(3)$ for Germany were accepted. The highest persistence of the transition probabilities of regimes was found for UK and the lowest persistence for Italy. For Italy in regime 1, standard errors are larger; this situation suggests higher volatility. The recessionary states illustrate a sharp increase in the standard error variability which denotes that economic recession periods are less stable than economic expansion periods. In MS-ARX models, the parameter estimations of OP variable 
Melike Bildirici, Fulya Özaksoy Sonustun

are statistically significant. Asymmetries in oil price-macro economy relationship can be moulded by price movements.

\subsection{Other Macroeconomic Policy Results}

For macro-economic policy analyses, it was used the MSI(3)-VARX(4) models in which AP and OP variables were taken as exogenous (See Table 5).To specify regime numbers, firstly, a linear VAR model was tested against a MS-VAR withh2 regimes, and the Ho hypothesis, which hypothesizes linearity, was rejected by using the LR tests statistics. Since it was realized that two regime models invalidating the linear model because they are incapable of explaining the correlations of the variables so, 3 regime models were regarded. Hence, secondly MS-VAR model with 2 regimes was tested against MS-VAR model with 3 regimes; Ho hypothesis implies that there are 2 regimes, were rejected and MSVAR model with 3 regimes was accepted as the optimal model because $L R$ statistic was greater than the $5 \%$ critical value of $\chi^{2}$. In this study, the number of regimes were determined as 3 .

The MSI(3)-VARX(4) model, which describes important changes in GDP of countries, is determined for analysis of effects of the volatility of OP and AP variables. Regime 1 describes crisis regime, regime 2 signs to moderate growth periods and regime 3 is high growth path. Regime 2 is determined to be the most persistent, which is also affirmed by the average duration of each regimes. The results of $\operatorname{Prob}(\mathrm{st}=1 \mid \mathrm{st}-1=1)=0.84, \operatorname{Prob}(\mathrm{st}=2 \mid \mathrm{st}-1=2)=0.93$ and $\operatorname{Prob}(\mathrm{st}=$ $3 \mid \mathrm{st}-1=3)=0.82$ have showed the regime persistences. Regime probabilities sign that dominant regime is the second one and transition probabilities reported the important asymmetries in business cycle. The estimated probability (i.e. Prob(st = $2 \mid s t-1=1)=0.11)$ reflects the low chance of a recession period is followed by moderate growth period. On the other hand, the estimated probability (i.e. Prob(st $=3 \mid \mathrm{st}-1=1)=0.03)$ gets a lower chance that recession period is followed by a high growth period. Ergodic probabilities present that dominant regime is the second one and transition probabilities report the important asymmetries in business cycles. The regime 2 signals to the most persistent phases.

The economic effects of oil shocks differ from another. Outcome of filtered and smooth probabilities and recursive estimates show these results. The claims of our model is that the oil and gold prices are efficient in all models and oil price variable is important to expound the behavior of business cycle in economies.

Regime shifting of moderate regimes are represented by higher growth rates of real GDP in MS-VARX models, some coefficients of oil price variable are negative and statistically significant. So, it can be interpreted that a negative impact of oil shocks on business cycle may occur. 
The Effects of Oil and Gold Prices on G7 Countries

Table 5. MSIH(3)-VARX(4)

\begin{tabular}{|c|c|c|c|c|c|c|}
\hline & FY & CY & UKY & USY & GY & ITY \\
\hline \multicolumn{7}{|c|}{ Regime-specific Intercept } \\
\hline $\mathrm{c}($ Reg.1) & $-0,10(1.78)$ & $-0,05(1.66)$ & $1.52(1.93)$ & $-0,41(1.82)$ & $1,11(1.85)$ & $-0,0121.98)$ \\
\hline $\mathrm{c}($ Reg.2) & $0.89(0.56)$ & $-0.85(2.01)$ & $-0.4(2.25)$ & $0.29(1.7)$ & $0.75(1.8)$ & $-0.094(1.98)$ \\
\hline $\mathrm{c}($ Reg.3) & $0.01(1.8)$ & $0.12(1.95)$ & $-0.1(3.01)$ & $0.027(1.65)$ & $-0.56(1.93)$ & $0.88(1.9)$ \\
\hline \multicolumn{7}{|c|}{ Regime -specific autoregressive coefficients } \\
\hline $\mathrm{FY}(-1)$ & $0,99(1.79)$ & $2,37(1.86)$ & $5,09(1.77)$ & $2,27(1.95)$ & $3,64(1.86)$ & $0,01(1.9)$ \\
\hline FY(-2) & $-0,67(0.45)$ & $-1,00(1.12)$ & $1,66(1.96)$ & $-1,47(1.86)$ & $0,98(2.11)$ & $0,2(2.78)$ \\
\hline $\mathrm{FY}(-3)$ & $0,27(1.89)$ & $1,54(2.12)$ & $0,928(2.01)$ & $1,12(902)$ & $-1,79(0.37)$ & $0,01(1.9)$ \\
\hline FY(-4) & $-0,12(2.21)$ & $-1,11(1.86)$ & $-3,51(1.93)$ & $-1,13(1.88)$ & $1,43(1.88)$ & $-0,02(1.6)$ \\
\hline CY(-1) & $-0,11(1.12)$ & $0,97(1.88)$ & $1,33(1.93)$ & $-0,23(1.88)$ & $-1,05(1.79)$ & $0,01(1.8)$ \\
\hline CY $(-2)$ & $0,22(1.818)$ & $-0,04(1.73)$ & $0,50(1.69)$ & $-0,31(1.72)$ & $1,16(1.80)$ & $0,01(1.9)$ \\
\hline CY(-3) & $-0,15(1.76)$ & $-0,62(0.12)$ & $-1,61(1.54)$ & $-1,05(1.15)$ & $-0,21(1.86)$ & $0,03(0.8)$ \\
\hline CY $(-4)$ & $0,10(1.45)$ & $0,25(1.79)$ & $-0,44(1.12)$ & $1,19(1.12)$ & $-1,17(1.83)$ & $-0,01(1.8)$ \\
\hline UKY $(-1)$ & $0,05(1.89)$ & $-0,24(1.8)$ & $0,19(1.86)$ & $0,08(1.88)$ & $-0,07(1.93)$ & $0,06(1.8)$ \\
\hline UKY(-2) & $-0,09(1.01)$ & $0,14(1.12)$ & $0,84(1.56)$ & $-0,13(1.78)$ & $0,12(1.73)$ & $0,51(2.8)$ \\
\hline UKY(-3) & $0,02(3.01)$ & $0,42(2.86)$ & $0,89(2.07)$ & $0,29(2.25)$ & $0,25(2.89)$ & $0,32(2,8)$ \\
\hline UKY $(-4)$ & $-0,02(1.93)$ & $0,01(1.98)$ & $-0,32(0.93)$ & $0,16(2.65)$ & $0,68(1.93)$ & $0,95(3.8)$ \\
\hline USY(-1) & $0,05(1.86)$ & $0,69(0.52)$ & $-0,41(0.85)$ & $1,14(2.78)$ & $-0,09(2.96)$ & $-0,01(0.8)$ \\
\hline USY(-2) & $0.018(2.85)$ & $0.39(2.01)$ & $0.792(1.86)$ & $0.413(1.75)$ & $-0.269(1.5)$ & $0.24(2.5)$ \\
\hline $\operatorname{USY}(-3)$ & $0.017(0.85)$ & $-0.58(1.89)$ & $-0.5(0.227)$ & $-0.41(1.89)$ & $0.103(2.58)$ & $-0.31(3.1)$ \\
\hline USY(-4) & $-0.603(2.9)$ & $0.22(2.36)$ & $0.314(4.75)$ & $0.468(2.01)$ & $0.149(1.89)$ & $0.34(1.8)$ \\
\hline GY(-1) & $0.012(2.20)$ & $-0.02(1.08)$ & $-0.06(1.81)$ & $-0.33(5.86)$ & $-0.29(1.73)$ & $-0.95(1.1)$ \\
\hline GY(-2) & $0.001(0.05)$ & $0.362(2.09)$ & $0.019(2.07)$ & $1.003(6.86)$ & $0.283(1.36)$ & $-0.56(2.5)$ \\
\hline GY(-3) & $-0.024(1.1)$ & $-0.027(1.9)$ & $0.025(1.13)$ & $-0.06(1.12)$ & $-0.18(2.42)$ & $0.32(2.6)$ \\
\hline GY(-4) & $0.506(2.86)$ & $-0.27(0.06)$ & $0.014(2.19)$ & $-0.41(1.36)$ & $-0.19(2.36)$ & $0.42(5.8)$ \\
\hline $\operatorname{ITY}(-1)$ & $0.129(1.09)$ & $0.308(1.86)$ & $-0.02(1.93)$ & $0.289(2.75)$ & $0.821(1.36)$ & $0.98(1.9)$ \\
\hline ITY(-2) & $-0.33(2.09)$ & $0.273(2.15)$ & $-0.88(1.18)$ & $-0.09(1.93)$ & $0.788(2.08)$ & $0.25(2.9)$ \\
\hline $\operatorname{ITY}(-3)$ & $-0.22(1.89)$ & $-0.16(1.56)$ & $-0.36(1.17)$ & $0.028(2.86)$ & $0.175(1.09)$ & $-0.19(2.8)$ \\
\hline ITY(-4) & $0.012(1.43)$ & $-0.08(0.02)$ & $0.05(2.27)$ & $0.347(2.85)$ & $0.096(1.14)$ & $0.68(1.6)$ \\
\hline $\mathrm{JY}(-1)$ & $0.017(1.32)$ & $-0.31(4.85)$ & $-0.16(1.07)$ & $-0.12(1.86)$ & $-0.18(0.03)$ & $-0.34(1.7)$ \\
\hline JY(-2) & $0.056(2.85)$ & $0.303(2.19)$ & $0.01(1.65)$ & $-0.54(3.35)$ & $0.436(1.92)$ & $0.68(1.8)$ \\
\hline$J Y(-3)$ & $0.35(1.089)$ & $0.323(2.09)$ & $-0.02(1.82)$ & $0.152(2.85)$ & $-0.49(1.83)$ & $0.45(0.2)$ \\
\hline JY(-4) & $0.445(1.33)$ & $0.401(1.93)$ & $0.251(1.15)$ & $0.561(0.13)$ & $0.59(2.0)$ & $0.56(1.5)$ \\
\hline OP & $1.20(2.869)$ & $0.22(2.86)$ & $0.441(2.12)$ & $0.283(2.85)$ & $0.82(1.13)$ & $1.0(2.56)$ \\
\hline $\mathrm{OP}(-1)$ & $-0,54(1.85)$ & $-4,94(1.86)$ & $-9,09(1.43)$ & $-3,02(1.36)$ & $-4,80(2.13)$ & $-0,3(1.38)$ \\
\hline $\mathrm{OP}(-2)$ & $0,12(2.856)$ & $-1,39(1.85)$ & $-1.24(1.83)$ & $-0,54(1.13)$ & $-1,24(1.39)$ & $-0,7(1.26)$ \\
\hline $\mathrm{OP}(-3)$ & $-0,82(0.33)$ & $-5,13(1.63)$ & $-6,86(2.28)$ & $-5,64(1.23)$ & $-7,43(1.63)$ & $-0,5(1.96)$ \\
\hline $\mathrm{OP}(-4)$ & $-0,17(1.96)$ & $-1,91(2.01)$ & $-2,52(1.43)$ & $0,62(2.28)$ & $-6,43(0.03)$ & $-0,36(2.9)$ \\
\hline AP & $-0,11(2.85)$ & $-4,23(1.87)$ & $-1,39(1.82)$ & $-0,30(1.96)$ & $-1.53(2.36)$ & $-0,78(2.8)$ \\
\hline $\mathrm{AP}(-1)$ & $0,63(1.93)$ & $-4,66(1.19)$ & $-1.34(2.83)$ & $-9,03(1.09)$ & $-5,82(0.23)$ & $0,43(2.4)$ \\
\hline $\mathrm{AP}(-2)$ & $0,38(2.21)$ & $-1,16(0.09)$ & $-1,82(1.13)$ & $-6,94(2.27)$ & $-1,20(1.92)$ & $0,61(3.7)$ \\
\hline $\mathrm{AP}(-3)$ & $1,18(2.85)$ & $-0,72(1.93)$ & $-1.53(2.86)$ & $2,80(1.85)$ & $-0,54(2.01)$ & $-0,82(5.7)$ \\
\hline $\mathrm{AP}(-4)$ & $-0,20(1.17)$ & $-0,76(2.02)$ & $-1,87(1.15)$ & $0,92(0.023)$ & $-1,12(1.03)$ & $0,73(2.3)$ \\
\hline \multicolumn{3}{|c|}{ Regime-specific standart error } & \multicolumn{4}{|c|}{ Transition robabilities } \\
\hline $\mathrm{SE}(\mathrm{R} 1)$ & \multicolumn{2}{|c|}{0,89} & $\mathrm{P}_{11}$ & \multicolumn{3}{|c|}{0,84} \\
\hline $\mathrm{SE}(\mathrm{R} 2)$ & \multicolumn{2}{|c|}{0,11} & $\mathrm{P}_{22}$ & \multicolumn{3}{|c|}{0.93} \\
\hline SE(R3) & \multicolumn{2}{|c|}{0,09} & $\mathrm{P}_{33}$ & \multicolumn{3}{|c|}{0.82} \\
\hline
\end{tabular}

DOI: 10.24818/18423264/52.3.18.06 
Melike Bildirici, Fulya Özaksoy Sonustun

\section{Conclusion}

This paper focuses on shock periods in the oil market since 1972, which analyzes the effects of oil and gold prices in business cycles by getting empirical results of different MS-VAR models' specifications. The countries which analyzed in this paper are the Canada, France, Germany, Italy, the United States and United Kingdom. These models were identified to determine different stages of the business cycle structures of each of the analyzed countries. The effects of OP, AP variables in the selected countries have been assessed statistically through the usage of MS-VAR analysis. Most of the business-cycle dates coincided with those denoted by ECRI and previous academic researches.

Countries were gathered in two groups and one of which is modelled with two regimes and the others with three regimes. MSIH(2)-ARX(4) model was accepted for Canada and the USA. In other group, MSIH(3) model for UK and Italy, MSIA for Germany were accepted. In MS-ARX models, the coefficients of $\mathrm{OP}$ variable were statistically significant. Asymmetries in macro economy-oil price relationship can be described by the rise of oil and gold prices.

The gold price has stronger effect on the crude oil prices, besides the reversed effect exist. It is clearly seen that volatility effect is the driving factor behind oil and gold price structures of the analyzed economies. And besides, price movements in gold and oil have decisive role on economic behaviors of the countries. The results have highlighted the importance of oil and gold prices on economic growth and welfare. The recent energy policies should be designed to meet this goal.

\section{REFERENCES}

[1] González, A. and Nabiyev, S. (2009), Oil Price Fluctuations and Its Effect on GDP Growth: A Case Study of USA and Sweden. Jönköpıng University, Bachelor thesis within Economics 1-35;

[2] Lescaroux, F. and Mignon, V. (2008), On the Influence of Oil Prices on Economic Activity and Other Macroeconomic and Financial Variables. CEPII, Working Paper 05: 1-43;

[3] Ogiri IH, Amadi SN, Uddin MM, Dubon P. (2013), Oil Price and Stock Market Performance in Nigeria: An Empirical Analysis. American Journal of Social and Management Sciences 4(1): 20-41;

[4] Tully, E. and Lucey, BM. (2007), A Power GARCH Examination of the Gold Market. Research in International Business and Finance 21: 316-325;

[5] Wang, KM. (2013), Can Gold Effectively Hedge Risks of Exchange Rate?.Journal of Business Economicsand Management 14(5), 833-851;

[6] Cologni, A. and Manera, M. (2007), Oil Prices, Inflation and Interestrates in a Structural Cointegrated VAR Model For the G-7 Countries. Energy Economics 30: 856-888; 
The Effects of Oil and Gold Prices on G7 Countries

[7] Tiwari, AK. and Sahadudheen I. (2015), Understanding the Nexus between Oil and Gold. Resources Policy 46: 85-91;

[8] Melvin, M. and Sultan, J. (1990), South African Political Unrest, Oil Prices, and the Time Varying Risk Premium in the Fold Futures Market. Journal of Futures Markets 10: 103-111;

[9] Reboredo, JC. (2013), Is Gold a Hedge or Safe against Oil Price Movements. Resources Policy 38: 130-137;

[10] Kydland, F. and Prescott, E. (1982), Time to Build and Aggregate Fluctuations. Econometrica 50(6): 1345-70;

[11] Rasche, RH. and Tatom, JA. (1977), The Effects of the New Energy Regime on Economic Capacity, Production and Prices. Economic Review, Federal Reserve Bank of St. Louis 59(4): 2-12.; Darby, MR. (1982). The price of oil and world inflation and recession. American Economic Review. 72(4): 738-751.; Hamilton JD. (1983). Oil and the macroeconomy since World War II. Journal of Political Economy 6(91), 228-248.; Burbidge, J. and Harrison, A. (1984). Testing for the effects of oil-price rises using vector autoregression. International Economic Review 25: 459-48. Bruno, MR. and Sachs, J. (1985). Economics of worldwide stagflation. Cambridge, MA: Harvard University Press.;Gisser, M. and Goodwin, TH. (1986). Crude oil and the macroeconomy: tests of some popular notions. Journal of Money, Credit and Banking 18: 95-103; Hooker, MA. (1996). What happened to the oil price macroeconomy relationship? Journal of Monetary Economics 38: 195-213. http://www.nuwireinvestor.com/articles/gold-and-oil-what-is-the-correlation51800.aspx

[12] Bruno and Sachs(1985); and Burbridge and Harrison(1984); Bruno, MR. and Sachs, J. (1981), Supply versus Demand Approaches to the Problem of Stagflation. In H. Giersch \& J. C. B. Tubingen (Eds.), Macroeconomic Policies for Growth and Stability;

[13] Mork, KA. (1989), Oil and the Macroeconomy when Prices Goes up and Down: An Extension of Hamilton's Results. Journal of Political Economy 1989; 97(3): 740-744; Mory, JF. (1993). Oil prices and economic activity: Is the relationship symmetric?. The Energy Journal 14(4): 151-161; Brown, SPA.,Yucel, MK. (2002). Energy prices and aggregate economic activity: An interpretative survey. Quarterly Review of Economic and Finance, 43: 193208; Zhang, Y., Fan, Y., Tsai, H. and Wei, Y. (2008). Spillover effect of US dollar exchange rate on oil prices. Journal of Policy Modeling 30: 973-991; Lardic, S. and Mignon, V. (2008). Oil prices and economic activity: an asymmetric cointegration approach. Energy Economics 30(3): 847855.http://dx.doi.org/10.1016/j.eneco.2006.10.010;:Nzimande, N. and Msomi, S. (2016). Oil price shocks and economic activity: The asymmetric cointegration approach in South Africa. SAEF Working Paper 01/05. MWG01, 1-15; 
Melike Bildirici, Fulya Özaksoy Sonustun

[14] Raymond, JE. and Rich, RW. (1997), Oil and the Macroeconomy: A Markov State-switching Approach. Journal of Money, Credit and Banking 29(2): 193-213.; Clements, MP. And Krolzig, HM. (2002). Can oil shocks explain asymmetries in the US business cycle. Empirical Economics 27(2): 185-204; Holmes, MJ. and Wang, P. (2003). Oil and the asymmetric adjustment of UK output: a Markov-switching approach. International Review of Applied Economics 17(2): 181-92; Bildirici, M., Aykaç Alp, E. and Bakırtaş, T. (2011). The great recession and the effects of oil price shocks and the U.S. recession: A Markov-Switching and TAR-VEC analysis. Journal of Energy and Development, 35(2): 215-79;

[15] Guo H. and Kliesen KL. (2005), Oil Price Volatility and US Macroeconomic Activity. Federal Reserve Bank of St. Louis, 57(6): 669-83;

[16] Hamilton JD. (2003), What is an Oil Shock?. Journal of Econometrics 113(2): 363-398;

[17] Cologni, A. and Manera, M. (2007), Oil Prices, Inflation and Interest Rates in a Structural Cointegrated VAR Model for the G-7 Countries. Energy Economics 30: 856-888;

[18] Hamilton JD. (1996), This İs what Happened to the Oil Price Macroeconomy Relationship. Journal of Monetary Economics 38(2): 215220 ;

[19] Krolzig, HM. (1997), Markov-Switching Vector Autoregressions: Modelling, Statistical Inference, and Application to Business Cycle Analysis. Berlin: Springer;

[20] Hamilton JD. (1989), A New Approach to the Economic Analysis of Nonstationary Time Series and the Business Cycle. Econometrica 57(2): 357-84;

[21] Krolzig, H. M. (2000), Predicting Markov-Switching Vector Autoregressive Processes. Oxford University. Working Paper 2000W31;

[22] Cologni, A. and Manera, M. (2009), The Asymmetric Effects of Oil Shocks on Output Growth: A Markov-Switching Analysis for the G-7 Countries. Economic Modelling 26: 1-29;

[23] Altuğ, S. and Bildirici, M. (2010), Business Cycles around the Globe: A Regime Switching Approach. Koç University-TUSIAD Economic Research Forum. Working Paper 1009. 